\title{
Management of Onion Purple Blotch Disease by using Fluorescent Pseudomonads
}

\author{
T. Anand* \\ Department of Plant Pathology, Tamil Nadu Agricultural University, \\ Coimbatore - 641 003, Tamil Nadu, India \\ *Corresponding author
}

Keywords

Alternaria porri, onion, fluorescent pseudomonads, seed treatment, soil application

Article Info

Accepted:

20 June 2021

Available Online:

10 July 2021

\section{A B S T R A C T}

Fifteen isolates of fluorescent pseudomonads were tested against the mycelial growth of Alternaria porri, the causal agent of purple blotch disease of onion. In vitro studies indicated that the isolate EFP1 exerted the maximum inhibition $(74.40 \%)$ on the mycelial growth showing $2.15 \mathrm{~cm}$ colony diameter of the pathogen as against $8.40 \mathrm{~cm}$ in the control. Two field trials were conducted one at Cotton Research Station Farm, Veppanthattai and another at Arumbavur village, Perambalur district, Tamil Nadu to test the efficacy of talc-based formulation of Pseudomonas (EFP1) against onion purple blotch disease. Among the treatments, Pseudomonas EFP1 applied as seed (bulb) treatment $(10 \mathrm{~g} / \mathrm{kg})+$ soil application (SA) $(2.5$ $\mathrm{kg} / \mathrm{ha})+3$ foliar spray (FS) (3g/lit) at 30,45 and 60 days after planting (DAP) recorded the least purple blotch incidence of 5.43, 7.05 and 6.24 PDI at 35, 50 and 65 days after planting (DAP), respectively. The same treatment also recorded the higher bulb yield of $15.4 \mathrm{t} / \mathrm{ha}$ ) with the $\mathrm{BC}$ ratio of 1:5.51.

\section{Introduction}

Onion (Allium cepa L.) is one of the most important vegetable cum spice crop grown in India. The crop is affected by various plant pathogens among which leaf blight was reported to be one of the major disease in India and it caused severe yield loss in many onion growing areas (Bhist and Agarwal,
1994). The disease caused extensive damage to bulbs as well as seed crop and the average intensity was found in the range of 5 to 45 per cent (Gupta et al., 1985). High relative humidity (80 to $90 \%)$ and optimum temperature $\left(24 \pm 1^{\circ} \mathrm{C}\right)$ are favour for further development of purple blotch disease and causing considerable yield losses. Shahanaz et al., (2007) reported losses about 50 to 100 per 
cent due to purple blotch disease. In Tamil Nadu also, the purple blotch earned by Alternaria porri is most destructive.

Different chemicals including systemic and contact fungicides have been used for management of this disease (Srivastava et al., 1999; Kanzaria et al., 2003 and Rahman et al., 2003). Due to health risk and pollution hazards by use of chemical fungicides in plant disease control, it is considered appropriate to minimize their use.

Biological control of plant pathogens through antagonistic microorganisms is potential, ecofriendly and a suitable approach apart from being a promising alternative to the use of chemicals.

Earlier studies indicated that seed treatment and foliar application of $P$. fluorescens prevented the pathogen infection and reduced the disease incidence (Ramamoorthy and Samiyappan, 2001). Several workers have reported the effectiveness of Pseudomonas in control of diseases caused by Alternaria (Sastrahidayat, 1995; Mathivanan et al., 2000; Patni et al., 2005; Sanjeet kumar et al., 2005; Rao, 2006). Similar to previous studies, to obtain an effective disease management strategy for the control of purple blotch disease in onion, different fluorescent pseudomonad strains were collected form onion growing areas and studied for their disease suppression activity under in vitro and field conditions.

\section{Materials and Methods}

\section{Isolation of pathogen}

Onion purple blotch pathogen Alternaria porri was isolated from onion leaves showing typical purple blotch symptoms, and pure cultures of the pathogen were obtained by the single hyphal tip method (Rangaswami, 1972).

\section{Isolation of antagonists}

One gram of rhizosphere soil near the root surface of a onion plant was collected and transferred to a $250 \mathrm{ml}$ conical flask containing $100 \mathrm{ml}$ of sterile water. After thorough shaking for $15 \mathrm{~min}$ in shaker, different dilutions were prepared. One $\mathrm{ml}$ of each $10^{-5}$ and $10^{-6}$ dilution was pipetted into sterile Petri dishes. King's B (KB) medium was poured and rotated and plates were incubated at room temperature $\left(28 \pm 2{ }^{\circ} \mathrm{C}\right)$ for $24 \mathrm{~h}$. The colonies with raised surface and fluorescent colour were isolated and subcultured (Vidhyasekaran and Muthamilan, 1995). Pure cultures of fluorescent pseudomonads were maintained on KB slants at $4^{\circ} \mathrm{C}$.

\section{In vitro testing of Pseudomonas strains on inhibition of mycelial growth of $A$. porri}

Fluorescent pseudomonad strains were tested for their inhibition on mycelial growth of $A$. porri by following the dual culture technique (Dennis and Webster, 1971). The bacterial culture was streaked at one side of a Petri dish ( $1 \mathrm{~cm}$ from the edge of the plate) plated with potato dextrose agar (PDA) medium. A mycelial disc ( $8 \mathrm{~mm}$ diameter) of ten days old culture of $A$. porri was placed on the opposite side in the Petri dish perpendicular to the bacterial streaks. The plates were incubated at room temperature $\left(28 \pm 2{ }^{\circ} \mathrm{C}\right)$ for seven days. The mycelial inhibition of pathogen was measured when the fungus covered the full plate in control.

\section{Preparation of talc-based bioformulation}

A loopful of $P$. fluorescens was inoculated into sterilized $\mathrm{KB}$ and incubated in a rotary shaker at $150 \mathrm{rpm}$ for $48 \mathrm{~h}$ at room temperature $\left(28 \pm 2{ }^{\circ} \mathrm{C}\right)$. After $48 \mathrm{~h}$ of incubation, the broth containing $9 \times 10^{8} \mathrm{cfu} / \mathrm{ml}$ was used for the preparation of talc-based 
formulation. To the $400 \mathrm{ml}$ of bacterial suspension, $1 \mathrm{~kg}$ of the talc powder (sterilized at $105{ }^{\circ} \mathrm{C}$ for $12 \mathrm{~h}$ ), calcium carbonate $15 \mathrm{~g}$ (to adjust the $\mathrm{pH}$ to neutral) and carboxymethyl cellulose (CMC) $10 \mathrm{~g}$ (adhesive) were mixed under sterile conditions, following the method described by Nandakumar et al., (2001). After shade drying for overnight, it was packed in polypropylene bag and sealed. At the time of application, the population of bacteria in talc formulation was $2.5-3 \times 10^{8} \mathrm{cfu} / \mathrm{g}$.

\section{Field experiments}

Two field trials were conducted one at Cotton Research Station Farm, Veppanthattai and another at Arumbavur (Farmers holdings), Permabalur district, Tamil Nadu, India to test the efficacy of talc-based formulation of Pseudomonas fluorescens (EFP1) against onion purple blotch disease. The trials were laid out with eight treatments and replicated thrice in a Randomized Block Design (RBD). The individual plot size of $5 \times 4 \mathrm{~m}^{2}$ was maintained for all treatments. The treatments of the experiments were T1- Pseudomonas EFP1 (seed treatment (ST) @ 10g/kg + 1 foliar spray (FS) @ 3g/lit at 30 days after planting (DAP), T2- Pseudomonas EFP1 (ST +2 FS at 30 and 45 DAP), T3- Pseudomonas EFP1 (ST + 3 FS at 30, 45 and 60 DAP), T4Pseudomonas EFP1 (Soil application (SA) @ $2.5 \mathrm{~kg} / \mathrm{ha}+\mathrm{ST}+1 \mathrm{FS}$ at $30 \mathrm{DAP})$, T5Pseudomonas EFP1 (SA + ST + 2 FS at 30 and 45 DAP), T6- Pseudomonas EFP1 (SA + $\mathrm{ST}+3 \mathrm{FS}$ at 30,45 and 60 DAP), T7Chlorothalonil (FS at 30 and 45 DAP), T8Untreated check

The severity of purple blotch disease was measured on 35, 50 and 60 DAP by using 0-5 scale (Sharma, 1986) and the details of scales are shown below:

\section{0 - No disease symptoms}

1 -A few spots towards tip covering 10 per cent leaf area.

2 -Several dark purplish brown patch covering up to 20 per cent leaf area.

3 -Several patches with paler outer zone covering up to 40 per cent leaf area.

4 -Leaf streaks covering up to 75 per cent leaf area or breaking of the leaves from center.

5 - Complete drying of the leaves or breaking of the leaves from center.

Per cent disease intensity (PDI) was calculated by using the following formula (Wheeler, 1969).

$\%$ disease index $=$ Sum of numerical ratings/Number of observations x 100/5

Bulb yield was also recorded in each treatment.

\section{Statistical analysis}

The data were analysed using the IRRISTAT version 92-1 programme developed by the biometrics unit, International Rice Research Institute, The Philippines. Percentage infection, growth and yield data were analyzed independently by trial. Data were subjected to analysis variances (ANOVA). Disease incidence data were arcsine transformed before analysis. The treatment means were compared by Duncan's Multiple Range test (DMRT) (Gomez and Gomez 1984).

\section{Results and Discussion}

Fifteen isolates of fluorescent pseudomonads were collected from different onion growing regions of Perambalur districts. Among the 15 fluorescent pseudomonad isolates tested, EFP1 isolate exerted the maximum inhibition $(74.40 \%)$ on the mycelial growth showing $2.15 \mathrm{~cm}$ colony diameter of the pathogen as against $8.40 \mathrm{~cm}$ in the control. This was 
followed by NMFP1 and ALFP1 recording 3.30 and $3.40 \mathrm{~cm}$ of the mycelial growth accounting for 60.71 and $59.52 \%$ inhibition over control, respectively (Table 1). Similarly, use of biocontrol strains for the management of plant pathogens has been exploited by several research workers (Radjacommare et al., 2002; Anand and Bhaskaran, 2009; Manikandan et al., 2010).

The inhibition of mycelial growth of the pathogen by fluorescent pseudomonds was probably due to competition and/or antibiosis.

The antagonism of fluorescent pseudomonads was also observed in the present studies in tune with the findings of various workers (Whipps, 2001; Ramamoorthy et al., 2002;
Saravanakumar et al., 2009). The results of field experiments revealed that Pseudomonas EFP1 applied as seed (bulb) treatment $(10 \mathrm{~g} / \mathrm{kg})+$ soil application $(\mathrm{SA})(2.5 \mathrm{~kg} / \mathrm{ha})+$ foliar spray (FS) (3g/lit) at 30, 45 and 60 days after planting (DAP) recorded the least purple blotch incidence of 5.43, 7.05 and 6.24 PDI at 35,50 and 65 DAP, respectively followed by seed (bulb) treatment $(10 \mathrm{~g} / \mathrm{kg})+$ soil application $(2.5 \mathrm{~kg} / \mathrm{ha})+$ foliar spray $(3 \mathrm{~g} / \mathrm{lit})$ at 30 and 45 DAP. The same treatment also recorded the higher bulb yield (15.4 t/ha) and $\mathrm{BC}$ ratio (1:5.51).

These treatments were found at par with each other and found to be superior to the recommended fungicide chlorothalonil (Table 2).

Table.1 Effect of different isolates of fluorescent pseudomonads on the mycelial growth of $A$. porri

\begin{tabular}{|c|c|c|c|c|}
\hline S. No & Isolate & Location & $\begin{array}{c}\text { Diameter of mycelial } \\
\text { growth }(\mathbf{c m})\end{array}$ & $\begin{array}{c}\text { Per cent inhibition over } \\
\text { control }\end{array}$ \\
\hline $\mathbf{1 .}$ & KFP1 & Kurumbalur & $4.62^{\mathrm{d}}$ & $\mathbf{4 5 . 0 0}$ \\
\hline $\mathbf{2 .}$ & AFP1 & Ammapalayam & $3.65^{\mathrm{bc}}$ & $\mathbf{5 6 . 5 5}$ \\
\hline $\mathbf{3 .}$ & VFP1 & Veppanthattai & $5.70^{\mathrm{f}}$ & $\mathbf{3 2 . 1 4}$ \\
\hline $\mathbf{4 .}$ & NFP1 & Navalur & $6.40^{\mathrm{g}}$ & $\mathbf{2 3 . 8 0}$ \\
\hline $\mathbf{5 .}$ & EFP1 & Esanai & $2.15^{\mathrm{a}}$ & $\mathbf{7 4 . 4 0}$ \\
\hline $\mathbf{6 .}$ & MFP1 & Melapuliyur & $7.00^{\mathrm{h}}$ & $\mathbf{1 6 . 6 7}$ \\
\hline $\mathbf{7 .}$ & LFP1 & Ladapuram & $5.50^{\mathrm{f}}$ & $\mathbf{5 0 . 0 0}$ \\
\hline $\mathbf{8 .}$ & EFP2 & Esanai & $4.20^{\mathrm{cd}}$ & $\mathbf{5 2 . 9 8}$ \\
\hline $\mathbf{9 .}$ & CFP1 & Chettikulam & $3.95^{\mathrm{c}}$ & $\mathbf{1 3 . 1 0}$ \\
\hline $\mathbf{1 0 .}$ & APFP1 & Alampadi & $7.30^{\mathrm{h}}$ & $\mathbf{6 0 . 7 1}$ \\
\hline $\mathbf{1 1 .}$ & NMFP1 & Natarmangalam & $3.30^{\mathrm{b}}$ & $\mathbf{2 2 . 6 2}$ \\
\hline $\mathbf{1 2 .}$ & KPFP1 & Koneripapalayam & $6.50^{\mathrm{g}}$ & $\mathbf{3 6 . 9 0}$ \\
\hline $\mathbf{1 3 .}$ & ARFP1 & Arumbavur & $5.30^{\mathrm{e}}$ & $\mathbf{4 6 . 4 3}$ \\
\hline $\mathbf{1 4}$ & EMFP1 & Eechampatti & $4.50^{\mathrm{d}}$ & $\mathbf{5 9 . 5 2}$ \\
\hline $\mathbf{1 5 .}$ & ALFP1 & Aalathur & $3.40^{\mathrm{b}}$ & $\mathbf{-}$ \\
\hline $\mathbf{1 6}$ & Control & - & $\mathbf{8 . 4 0}^{\mathrm{i}}$ & \\
\hline
\end{tabular}

Values are mean of three replications.

Means in a column followed by same superscript letters are not significantly different according to Duncan's multiple range test at $\mathrm{P}=0.05$. 
Table.2 Effect of talc-based formulation of Pseudomonas against onion purple blotch disease (Pooled mean of two field trials)

\begin{tabular}{|c|c|c|c|c|c|}
\hline \multirow[t]{2}{*}{ Treatments } & \multicolumn{3}{|c|}{ PDI } & \multirow{2}{*}{$\begin{array}{l}\text { Yield } \\
(\mathrm{t} / \mathrm{ha})\end{array}$} & \multirow[t]{2}{*}{ BCR } \\
\hline & 35 DAP & 50 DAP & 65 DAP & & \\
\hline $\begin{array}{l}\text { T1- Pseudomonas (seed treatment (ST) } \\
@ 10 \mathrm{~g} / \mathrm{kg}+1 \text { foliar spray (FS) @ 3g/lit } \\
\text { at } 30 \text { days after planting (DAP) }\end{array}$ & $8.70^{\mathrm{b}}$ & $13.42^{\mathrm{c}}$ & $19.54^{\mathrm{d}}$ & $9.2^{\mathrm{d}}$ & 2.82 \\
\hline $\begin{array}{c}\text { T2- Pseudomonas EFP1 (ST + } 2 \text { FS at } \\
30 \text { and } 45 \text { DAP })\end{array}$ & $8.10^{\mathrm{b}}$ & $10.35^{\mathrm{b}}$ & $15.39^{c}$ & $11.6^{c}$ & 3.54 \\
\hline $\begin{array}{c}\text { T3- Pseudomonas EFP1 (ST + } 3 \text { FS at } \\
\text { 30, } 45 \text { and } 60 \text { DAP) }\end{array}$ & $8.47^{\mathrm{b}}$ & $10.12^{b}$ & $12.34^{\mathrm{b}}$ & $13.9^{\mathrm{b}}$ & 4.25 \\
\hline $\begin{array}{l}\text { T4- Pseudomonas EFP1 (Soil } \\
\text { application (SA) @ } 2.5 \mathrm{~kg} / \mathrm{ha}+\mathrm{ST}+1 \\
\text { FS at } 30 \text { DAP) }\end{array}$ & $5.64^{\mathrm{a}}$ & $9.40^{\mathrm{b}}$ & $11.45^{\mathrm{b}}$ & $13.5^{\mathrm{b}}$ & 4.10 \\
\hline $\begin{array}{c}\text { T5- Pseudomonas EFP1 (SA + ST + } 2 \\
\text { FS at } 30 \text { and } 45 \text { DAP) }\end{array}$ & $5.90^{\mathrm{a}}$ & $7.52^{\mathrm{a}}$ & $7.76^{\mathrm{a}}$ & $15.0^{\mathrm{a}}$ & 5.46 \\
\hline $\begin{array}{c}\text { T6- Pseudomonas EFP1 }(\mathrm{SA}+\mathrm{ST}+3 \\
\text { FS at 30, } 45 \text { and } 60 \text { DAP })\end{array}$ & $5.43^{\mathrm{a}}$ & $7.05^{\mathrm{a}}$ & $6.24^{\mathrm{a}}$ & $15.4^{\mathrm{a}}$ & 5.51 \\
\hline T7- Chlorothalonil (Standard check) & $9.54^{\mathrm{b}}$ & $11.96^{\mathrm{bc}}$ & $17.50^{\mathrm{e}}$ & $11.0^{\mathrm{c}}$ & 3.23 \\
\hline T8- Untreated check & $18.22^{\mathrm{c}}$ & $29.47^{d}$ & $46.74^{\mathrm{f}}$ & $7.8^{\mathrm{e}}$ & - \\
\hline
\end{tabular}

Values are means of three replications. In a column, means followed by a common letter are not significantly different at $5 \%$ level by DMRT.

The results of present study are in line with Yadav et al., (2013) who found Pseudomonas fluorescens--I $(0.5 \%)$ was most antifungal against onion leaf blight caused by $A$. porri and recorded significantly least mean disease intensity (37.19\%) and gave maximum bulb yield (27183 kg/ha) and higher $\mathrm{BC}$ ratio $(1: 13.87)$.

\section{References}

Anand, T. and Bhaskaran, R. 2009. Exploitation of plant products and bioagents for the ecofriendly management of chilli fruit rot disease. J. Plant Prot. Res., 49(2):195203.

Bisht, M. and Agarwal, G. 1994. Investigation of purple blotch of onion in India. Acta Hortic., 360:359-361.

Dennis, C. and Webster, J. 1971. Antagonistic properties of species groups of Trichoderma I. production of nonvolatile antibiotics. Trans Brit. Mycol. Soc., 57:2539.

Gupta, R. P., Srivastava, V. K., Pandey U. B. and
Usha, M. 1985. Strategy to control field disease of onion. Proceedings of the National Workshop on Onion, December 1983, Nashik, India, pp. 48-50.

Kanzaria, M. V., Vaddoria, M. A., Golani, L. J. and Patel, R. K. 2003. Management of stalk blight disease of onion seed crop. Approaches for sustainable development of onion and garlic. National Horticultural Research and Development Foundation, Nashik, pp. 320-323.

Manikandan, R., Saravanakumar, D., Rajendran, L., Raguchander, T., Samiyappan, R. 2010. Standardization of liquid formulation of Pseudomonas fluorescens Pf1 for its efficacy against Fusarium wilt of tomato. Biol Control, 54:83-89.

Mathivanan, N., Srinivasan, K. and Chelliah, S. 2000. Field evaluation of Trichoderma viride Pers. Ex. S. F. Gray and Pseudomonas fluorescence Migula against foliar disease of groundnut and sunflower. J. Biol. Contl., 14:31-34.

Nandakumar, R., Babu, S., Viswanathan, R., Sheela, J., Raguchander, T. and Samiyappan, R. 2001. A new 
bioformulation containing plant growth promoting rhizobacterial mixture for the management of sheath blight and enhanced grain yield in rice. Biocontrol, 46(4):493- 510.

Patni, C. S., Kolte, S. J. and Awasthi, R. P. 2005. Efficacy of botanicals against Alternaria blight (Alternaria brsssicae) of mustard. Indian Phytopath., 58:426-430.

Radjacommare, R., Nandakumar, R., Kandan, A., Suresh, S., Bharathi, M., Raguchander, T. and Samiyappan, R. 2002. Pseudomonas fluorescens based bioformulation for the management of sheath blight and leaf folder in rice. Crop Prot., 21:671-677.

Rahman, M. A., Chiranjeevi, C. H. and Reddy, I. P. 2003. Management of leaf blight disease of onion. Approaches for sustainable development of onion and garlic. National Horticultural Research and Development Foundation, Nashik. pp. 311-314.

Ramamoorthy, V. and Samiyappan, R. 2001. Induction of defense-related genes in Pseudomonas fluorescens treated chilli plants in response to infection by Colletotrichum capsici. J. Mycol. Plant Pathol., 31:146-155.

Ramamoorthy, V., Raguchander, T. and Samiyappan, R. 2002. Enhancing resistance of tomato and hot pepper to Pythium diseases by seed treatment with fluorescent pseudomonads. Eur. J. Plant Pathol. 108:429-441.

Rangaswamy G. 1972. Diseases of Crop Plants in India. Prentice Hall of India Pvt. Ltd., New Delhi, India, 504 pp.

Rao, M. S. L. 2006. Studies on seed borne fungal disease of sunflower and their management. Ph.D. Thesis, Univ. Agric. Sci., Dharwad (India).
Sanjeet Kumar, J. P., Upadhyay and Sanjeev Kumar. 2005. Bio control of Alternaria leaf spot of Vicia faba using antagonistic fungi. J. Biol. Contl., 20:247-251.

Saravanakumar, D., Lavanya, N., Muthumeena, K., Raguchander, T. and Samiyappan, R. 2009. Fluorescent pseudomonad mixtures mediate disease resistance in rice plants against sheath rot (Sarocladium oryzae) disease. Biocontrol, 54:273-286.

Sastrahidayat, I. R. 1995. Integrated control of purple blotch disease (Alternaria porri) on garlic. Agrivita, 18:36-41.

Shahanaz, E., Razdan, V. K. and Raina, P. K. 2007. Survival, dispersal and management of foliar blight pathogen of onion. $J$. Mycol. Pl. Pathol., 37(2):213 - 214.

Sharma, S. R. 1986. Effect of fungicidal sprays on purple blotch and bulb yield. Indian Phytopathology, 39(1):72-82.

Srivastava, P. K., Tiwari, B. K. and Srivastava, K. J. 1999. Effect of different fungicides and spray interval on the control of purple blotch disease of late kharif onion. News letter NHRDF, 19(4):7-9.

Vidhyasekaran, P. and Muthamilan, M. 1995. Development of formulations of Pseudomonas fluorescens for control of chickpea wilt. Plant Dis., 79:782-786.

Wheeler, B. E. J. 1969. An Introduction to Plant Diseases. Jhon Wiley and Sons Ltd., London.

Whipps, J. M. 2001. Microbial interactions and biocontrol in the rhizosphere. $J$. Exponential Bot., 52:487-511.

Yadav P. M., Rakholiya K. B. and Pawar D. M. 2013. Evaluation of bioagents for management of the onion purple blotch and bulb yield loss assessment under field conditions. The Bioscan, 8(4): 1295-1298.

\section{How to cite this article:}

Anand, T. 2021. Management of Onion Purple Blotch Disease by using Fluorescent Pseudomonads. Int.J.Curr.Microbiol.App.Sci. 10(07): 592-597. doi: https://doi.org/10.20546/ijcmas.2021.1007.064 